\title{
Beyond Blaming the Victim: Toward a More Progressive Understanding of Workplace Mistreatment
}

\author{
Lilia M. Cortina, Verónica Caridad Rabelo, and Kathryn J. Holland \\ University of Michigan
}

\begin{abstract}
Theories of human aggression can inform research, policy, and practice in organizations. One such theory, victim precipitation, originated in the field of criminology. According to this perspective, some victims invite abuse through their personalities, styles of speech or dress, actions, and even their inactions. That is, they are partly at fault for the wrongdoing of others. This notion is gaining purchase in industrial and organizational (I-O) psychology as an explanation for workplace mistreatment. The first half of our article provides an overview and critique of the victim precipitation hypothesis. After tracing its history, we review the flaws of victim precipitation as catalogued by scientists and practitioners over several decades. We also consider realworld implications of victim precipitation thinking, such as the exoneration of violent criminals. Confident that I-O can do better, the second half of this article highlights alternative frameworks for researching and redressing hostile work behavior. In addition, we discuss a broad analytic paradigm-perpetrator predation-as a way to understand workplace abuse without blaming the abused. We take the position that these alternative perspectives offer stronger, more practical, and more progressive explanations for workplace mistreatment. Victim precipitation, we conclude, is an archaic ideology. Criminologists have long since abandoned it, and so should we.
\end{abstract}

Keywords: victim precipitation, perpetrator predation, victimization, victim blaming, workplace violence, aggressive behavior

Lilia M. Cortina, Departments of Psychology and Women's Studies, University of Michigan; Verónica Caridad Rabelo, Departments of Psychology and Women's Studies, University of Michigan, now in the Management Department, College of Business, San Francisco State University; Kathryn J. Holland, Departments of Psychology and Women's Studies, University of Michigan, now in the Department of Psychology and Women's and Gender Studies Program, University of Nebraska.

This article extends arguments appearing in the following chapter: Cortina, L. M. (2017). From victim precipitation to perpetrator predation: Toward a new paradigm for understanding workplace aggression. In N. Bowling \& M. S. Hershcovis (Eds.), Research and theory on workplace aggression (pp. 121-135). New York: Cambridge University Press. Many thanks to Sandy Hershcovis, Mindy Bergman, Kim Lonsway, Abby Stewart, Rita Seabrook, and Jennifer Freyd for their feedback on earlier versions of this article.

Correspondence concerning this article should be addressed to Lilia M. Cortina, University of Michigan, Department of Psychology, 530 Church Street, Ann Arbor, MI 48109. E-mail: lilia@umich.edu 
Theories of human aggression can inform research, policy, and practice in organizations. One such theory proposes that some victims invite abuseeven violence-through their personalities, styles of speech or dress, actions, and sometimes their inactions. In other words, they are partly to blame for the transgressions of others. This victim precipitation hypothesis originated in the field of criminology, but it fell out of favor in that discipline some time ago. In recent years, however, this concept has caught hold in industrialorganizational (I-O) psychology. This trend, we argue, is troubling.

This article provides an overview and critique of victim precipitation research. We chart the history of the victim precipitation hypothesis, from research on homicide (dating back to the 1940s) to rape (1960s) to abusive supervision on the job (2000s). We also review analyses of victim precipitation stemming from multiple fields of science and practice. In addition, we present some of the practical consequences that emerge (e.g., in the investigation and adjudication of crime) when victim precipitation ideology holds sway.

Confident that I-O psychology can do better than victim precipitation, the second half of this article highlights alternative models for researching and redressing workplace mistreatment. For purposes of illustration, we detail three frameworks that seem especially promising for advancing science and practice in this domain. We also review perpetrator predation, a broad analytic paradigm that explains the same workplace dynamics without blaming one person for the misdeeds of another (Cortina, 2017). Importantly, this framework does not assert that victim characteristics are irrelevant to workplace mistreatment, but rather that the person responsible for those characteristics being relevant is the perpetrator (not the victim). We posit that these alternative perspectives offer stronger, more practical, and more progressive explanations for victimization in organizations.

\section{The Troubled History of Victim Precipitation \\ Rise of a Model}

Over 75 years ago, criminologist Hans von Hentig and defense attorney Beniamin Mendelsohn pioneered the victim precipitation model. They proposed that some victims provoke their own victimization through their character or behavior, often unwittingly. As von Hentig (1940) wrote, "the human victim in many instances seems to lead the evil-doer actively into temptation. The predator is - by varying means-prevailed upon to advance against the prey. If there are born criminals, it is evident that there are born victims" (p. 303). Arguing that the victim in these cases "shapes and molds the criminal," von Hentig (1948, p. 384) suggested that victims deserve some of the blame for the crimes that befall them. Mendelsohn (1956) went so far as to construct a taxonomy of victims that centered on their level of culpability; 
categories ranged from completely innocent victims (e.g., children) to voluntary victims who share equal guilt with their offenders (e.g., dying in a suicide pact with a spouse) to victims who are the most guilty (e.g., assailants dying at the hands of their victims).

Criminologists and criminal defense attorneys flocked to the victim precipitation hypothesis in the mid-20th century, often as an explanation for violent crime. For instance, Marvin Wolfgang (1957) studied "victim precipitated criminal homicide," referring to situations where a person had initiated physical attack prior to being killed by the target of that attack (e.g., a man beats his girlfriend, and in self-defense she stabs him to death). Wolfgang went on to become one of the most influential criminologists in the English-speaking world (Cohn \& Farrington, 1994). Another criminologist, Menachem Amir (1967), wrote about "victim precipitated forcible rape," meaning:

\footnotetext{
... those rape situations in which the victim actually, or so it was deemed, agreed to sexual relations but retracted before the actual act or did not react strongly enough when the suggestion was made by the offender(s). The term applies also to cases in risky or vulnerable situations, marred with sexuality, especially when the victim uses what could be interpreted as indecency in language and gestures. (p. 495)
}

When Amir (1967) found cases fitting this description in Philadelphia Police Department files, he concluded that these victims had been "precipitators" of their own rapes, rendering their rapists "less guilty" (p. 502).

The psychoanalytic community embraced the ideology of victim precipitation as well. Mendelsohn, for example, published an important article in the Revue Française de Psychanalyse (French Review of Psychoanalysis; 1958). Moving from proposition to practice, therapies later emerged for "remotivating" victims to stop soliciting abuse. For instance, psychoanalyst Irwin $\mathrm{Ku}$ tash (1978) used von Hentig, Mendelsohn, and Wolfgang as a springboard and wrote that a victim:

\footnotetext{
... may compulsively and repetitively invite attack to atone for unconscious guilt feelings. Explorations of the victim's history can bring about the insight that all the victimage [sic] is more than coincidence and that he has had a part in promoting it. By zeroing in on the feelings during the victiming [sic] and asking the person when he experienced these feelings before, the therapist can help the victim get back to these previous incidents-perhaps all the way back to childhood experiences with parents. Associating to the feelings in dreams may have the same effect. (pp. 459-460)
}

Using classic psychoanalytic terms and techniques, the ultimate goal of this treatment is to "prevent the repetition of the invitation to be aggressed against" (Kutash, 1984, p. 59).

\section{Demise of a Model}

In the late 20th century, victim precipitation research came under heavy fire on multiple fronts (e.g., Berger \& Searles, 1985; Eigenberg \& Garland, 2003; 
Elias, 1986; Franklin \& Franklin, 1976; LeGrand, 1973; Ressler, Burgess, Douglas, Hartman, \& D’Agostino, 1986; Timmer \& Norman, 1984; Weis \& Borges, 1973). Criminologists lambasted it for logical inadequacies, questionable evidence, unfounded assumptions, untestable hypotheses, and unwarranted generalizations. For instance, some took issue with the circular reasoning inherent in the model, such that the independent variable (victim precipitation) falls apart without the dependent variable (victimization). This becomes obvious when we attempt to study one without the other: "for example, a woman walking alone at night on an unlighted street ... can hardly be thought of as engaging in crime-precipitative behavior if no criminal act takes place" (Franklin \& Franklin, 1976, p. 128). Researchers also identified deficits in the empirical record cited as support for the victim precipitation model. Part of Amir's (1967) so-called evidence of victimprecipitated rape, for example, was the "bad reputations" (p. 497) attached to victims prior to their assaults.

Because victim precipitation research generally ignored social conditions and institutions in the etiology of crime, many saw dangerous consequences in this work. Sociologists decried it for fueling regressive victim-blaming attitudes and ineffective crime prevention programs: "The 'ideology of victim precipitation'-by blaming the individual crime victimonly serves to divert attention and resources away from the structural causes of crime and the structural changes required by a less criminogenic society" (Timmer \& Norman, 1984, p. 63). Political scientist Robert Elias (1986) echoed similar sentiments, observing how victim precipitation "... has focused our attention away from law-enforcement failures and has made victims responsible not only for their victimization, but for preventing future attacks. Taking a very individualized view, it has attributed crime to personal failings, directing us away from institutional or structural flaws" (p. 89). As the criticisms mounted, scholars across the social sciences discarded victim precipitation as a reasonable explanation for crime.

On another front, the 1960s and 1970s brought the women's movement and a new wave of feminist mobilization against social inequality. Activists drew the nation's attention to violence against women, demanding that it not be ignored, excused, or denied. Research exploded in this area, and among other things it dismantled victim precipitation explanations of rape. For example, sociologists Ronald Berger and Patricia Searles (1985, p. 9) rejected the spurious claims implied by the victim precipitation model, which "assumes that the offender rests in a passive state and is set into motion primarily by the victim's behavior, that the victim's behavior is a necessary and sufficient condition for the offense, and that the intent of the victim can be inferred from his or her resultant victimization." Adding that "the concept 
merely converts sexist rationalizations into a causal explanation," they urged that it be abandoned (Berger \& Searles, 1985, p. 9).

Rape researchers also exposed disturbing repercussions of victim precipitation ideology. If a woman has participated in the chain of events that ultimately "caused" her sexual assault (as per victim precipitation), then she is partly to blame for that crime. This line of thinking lends itself to questions about her assailant's guilt, sometimes to the point of exoneration: "the victim's behavior becomes grounds for granting a 'reasonable doubt' to the offender's criminal intent in a court of law" (Berger \& Searles, 1985, p. 9; see also LeGrand, 1973). Victim precipitation proponents agreed with this reduction in rapist culpability; on the topic of rape, Amir (1967) stated that this model "does not make any offender innocent but allows us to consider some of these men, at least, less guilty and leads us to consider that the victim is perhaps also responsible for what happened to her" (p. 502). Put simply, the victim precipitation model helps violent predators escape penalty for their wrongdoing (Cortina, 2017).

Victim precipitation often crops up to explain "crimes of personal violence committed by (mostly) men against (mostly) women" (Meloy \& Miller, 2010, p. 11). Many other criminal offenses are never explained using this model. For example, if a family endures a home invasion and burglary, it typically does not face accusations of "inviting" crime by having nice things (Cortina, 2017). When people die in automobile accidents, they are not thought to have solicited vehicular homicide by driving their cars on the freeway. This points to a worrisome issue: "Why is it that we tend to sympathize with someone who is mugged, burglarized, or injured by a drunk driver, yet victims of male-on-female violence often experience victim blaming and self-blame?" (Meloy \& Miller, 2010, p. 7). Some answers to this question lie in cultural myths and supports for rape.

Victim precipitation ideas are central to rape mythology, a concept developed in the 1970s (e.g., Brownmiller, 1975; Schwendinger \& Schwendinger, 1974). Pervasive in our society, rape myths deny the reality of sexual violence and, when denial becomes impossible, justify it (e.g., Burt, 1980; Cowan, 2000; Lonsway \& Fitzgerald, 1994; Payne, Lonsway, \& Fitzgerald, 1999; Timmer \& Norman, 1984). These fallacies "deliberately obscure the true nature of rape" (Brownmiller, 1975, p. 312). A core myth is that women provoke men to assault them sexually-if not through their attire or behavior then through their lack of behavior (e.g., failure to fend off a rapist). In other words, rape myths assert that victims "ask for it," making their rapes seem more reasonable and their rapists less responsible. Psychologists Kim Lonsway and Louise Fitzgerald $(1994,1995)$ show how endorsement of these fictions serves different functions for men and women: "Its critical function for men is to justify male sexual violence, 
whereas for women it is to deny personal vulnerability" (Lonsway \& Fitzgerald, 1995, p. 709).

Not without consequence, rape mythology looms large in criminal justice proceedings. Research has demonstrated how these beliefs distort police, prosecutor, and jury decision making (e.g., Brekke \& Borgida, 1988; Coates $\&$ Wade, 2004; Lonsway \& Fitzgerald, 1994; Tetreault, 1989). For example, recent investigations by Rebecca Campbell and colleagues (2015) suggest that rape myths factored into law enforcement decisions not to submit thousands of rape kits to labs for forensic analysis. Instead of being tested for their evidentiary value, these biological samples were shelved in police storage for decades, all but forgotten (e.g., Human Rights Watch, 2010; The Weiner Report, 2002). This demonstrates how acceptance of myths surrounding sexual violence has practical repercussions that are very real and very alarming.

Similar myths deny and justify sexual harassment in organizations. A common fallacy is that some women "ask for" harassment with inappropriate attire or language on the job, so they are partly to blame for the wrongdoing that ensues (Lonsway, Cortina, \& Magley, 2008). According to empirical research, these misconceptions about workplace mistreatment go hand in hand with rape myths and generally hostile attitudes toward women (Lonsway et al., 2008). This body of evidence on cultural mythologies concerning gendered violence, documented by psychologists and sociologists over 40 years, exposes the harms of victim precipitation thinking (Cortina, 2017).

Not only scientists but also practitioners in law enforcement have rejected the victim precipitation hypothesis. For example, agents at the Behavioral Sciences Unit of the Federal Bureau of Investigation (FBI) have found limited utility in victim precipitation ideas, instead focusing on patterns of thought and (mis)perception among criminal offenders (Ressler et al., 1986). Again turning to the example of sexual assault, the International Association of Chiefs of Police (IACP, a professional organization for law enforcement leadership) rejects notions of victim precipitation, advising that police should "reassure victims that, regardless of their behavior, no one has the right to sexually assault them" (IACP, 2005, p. 4). Instead of scrutinizing victims, the IACP directs sexual assault investigators to focus principally on (alleged) perpetrators: "An effective investigation will concentrate on gathering as much evidence as possible on the suspect ... not on the victim's character, behavior, or credibility" (IACP, 2005, p. 6).

In summary, multiple scientist and practitioner communities have analyzed victim precipitation ideology and rejected it as flawed, even dangerous. Today, this model has fallen out of favor within criminology-the discipline that gave rise to it. For example, among the top-five highest-impact criminology journals (Criminology, Crime and Delinquency, Criminal Justice and Behavior, Sexual Abuse, and Journal of Criminal Law and Criminology), only 
three articles referenced "victim precipitation" (in a positive light) during the decade from 2006 to 2015. Likewise, searches of the top political science journals (American Political Science Review, American Journal of Political Science, Journal of Politics, and Political Science Quarterly) turn up exactly one contemporary reference to the victim precipitation hypothesis; this article only mentions the model in passing, noting that it is "rightly criticized for blaming victims" (Bateson, 2012, p. 581). In short, recent decades have witnessed a sharp decline in victim precipitation endorsement across the social sciences. I-O psychology, however, is bucking this trend.

\section{Victim Precipitation of Workplace Aggression? \\ Resurrection of a Model}

Though many scientists and practitioners have jettisoned victim precipitation as an explanation for aggression, some in I-O are embracing this notion. In the context of organizations, the victim precipitation hypothesis holds that victims of workplace abuse often provoke their own victimization, unwittingly or otherwise. The basic argument is that some employees (e.g., those who are unhappy, unpleasant, underperforming) "consciously or unconsciously participate in the sequence of events that leads to their becoming targets" (Aquino \& Byron, 2002, p. 72). This line of research gestures to psychodynamic concepts (e.g., unconscious invitations, wish fulfillment), which is rare in I-O psychology. Nevertheless, the popularity of this model is on the rise. A Google Scholar search for articles including the terms "workplace," "victim precipitation," and varieties of interpersonal mistreatment (any of the following: "mistreatment," "abuse," "victimization," "hostility," "bullying," "aggression," or "undermining") returns 65 works published between 2001 and 2005. This number leaps to 153 between 2006 through 2010, and it soars to 361 in the years 2011 through 2015. Figure 1 graphically depicts these publication trends over time. Victim precipitation is not central to all of these articles; still, this concept is clearly gaining purchase in I-O psychology.

The victim precipitation hypothesis is turning up across the organizational literature. For example, scholars have drawn on this notion in attempts to explain abusive supervision (Chan \& McAllister, 2014; Henle \& Gross, 2014; Tepper, Duffy, Henle, \& Lambert, 2006; Tepper, Moss, \& Duffy, 2011), workplace victimization (e.g., Aquino, 2000; Aquino \& Bradfield, 2000; Aquino \& Byron, 2002; Aquino, Grover, Bradfield \& Allen, 1999; Aquino \& Lamertz, 2004), workplace bullying (Samnani, 2013; Samnani \& Singh, 2015), workplace exclusion (Scott, Restubog, \& Zagenczyk, 2013), workplace ostracism (Wu, Wei, \& Hui, 2011), workplace incivility (Milam, Spitzmueller, \& Penney, 2009), and negative workplace gossip (Wu, Birtch, Chiang, \& Zhang, in press). Some of this work is seeing publication in the top journals of our field, including Journal of Applied Psychology, Personnel 


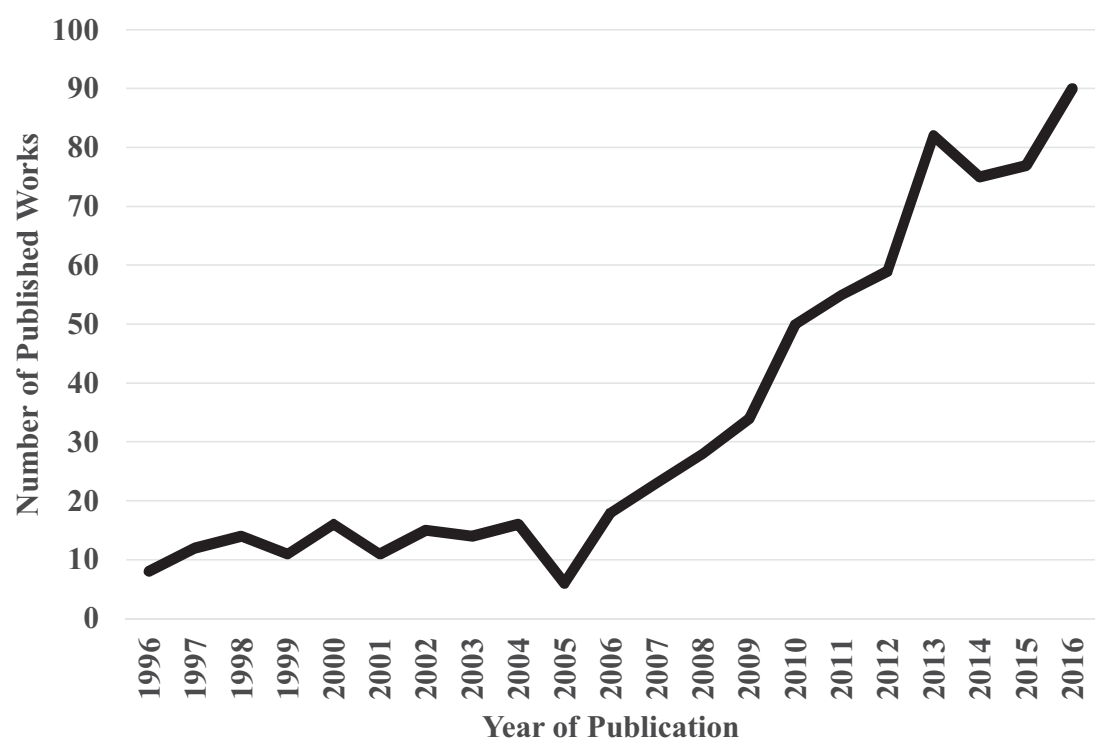

Figure 1. Results of a Google Scholar search for published works, 1996-2016, including the terms "workplace," "victim precipitation," and varieties of interpersonal mistreatment (any of the following: "mistreatment," "abuse," "victimization," "hostility," "bullying," "aggression," or "undermining").

Psychology, Journal of Management, and both Academy of Management Journal and Review. These recent developments, we argue, are cause for concern.

When Karl Aquino (2000, p. 172) asserted that the "concept of victim precipitation is a well-developed component of criminal victimology," he did not mention that the criticisms of victim precipitation are just as welldeveloped (if not more so). Victim precipitation research still suffers from the defects documented in criminology, sociology, psychology, political science, feminist studies, and law enforcement. This hypothesis still blames one individual for the transgressions of another. Even when victim blame is not the intent of the researchers, this is what happens when they invoke this model. In other words, "wherever victim precipitation is offered as an explanation, it serves to place responsibility on the victim: you cause, or help to cause, your own victimization" (Timmer \& Norman, 1984, p. 65).

In fact, when the victim precipitation hypothesis informs scientific questions, this leads scientists (as well as police and prosecutors) to focus on victims, with questions about their personalities (e.g., neurotic? disagreeable?), behaviors (submissive? provocative?), performance (low? high?), and so on. When the aggression takes a sexual turn, the (often female) victim's manner of speech, dress, and demeanor also become objects of scrutiny, framed as potential provocative factors in the abuse (Cortina, 2017). Victim precipitation arguments can make misconduct seem justified, because "the concept of 
victim precipitation provides a cultural framework which offenders can use to rationalize their behavior" (Eigenberg \& Garland, 2003, p. 32). Again, this happens even when it is far from the intent of the scientists and practitioners invoking the model.

Unintended consequences of victim precipitation ideology present psychologists with an ethical dilemma. The American Psychological Association (APA) Code of Ethics dictates that, in both science and practice, we must assess potential risks and benefits of our work, ensure that benefits outweigh costs, and avoid or minimize harms; these ideals are central to the principle of beneficence. We must therefore think carefully about possible repercussions of endorsing concepts like victim precipitation. As Elias (1986, p. 85) noted over 30 years ago,

While we cannot impede scientific study simply because our findings might be misapplied or misunderstood, we nevertheless must recognize their likely effects. For example, what will be the impact of this statement taken from [Amir'] rape study: "in a way, the victim is always the cause of crime." Victim precipitation theories may, unwittingly, rationalize our blaming victims for their victimization and for shifting the burden and responsibility of crime control onto the victim.

Just as problematic, victim precipitation arguments deflect attention away from wrongdoers and the social conditions that set them off.

Interventions addressing sexual violence in military work help illustrate the perils of victim precipitation ideology. Take, for example, the sexual assault prevention poster at Wright Patterson Airforce Base that advised personnel to "Avoid Becoming a Victim." The poster then listed eight tips, such as "Try to avoid areas that are secluded" and "Socialize with people who share your values" (Wiederspahn, 2013). These recommendations imply that employees have control over the conduct of others, including violent conduct; it then follows that, if violence ensues, the victim is at fault for failing to prevent it (consistent with the notion of victim precipitation; Cortina, 2017). Such messaging campaigns could instead hold personnel accountable for their own (mis)behavior. Under the headline "Avoid becoming a criminal," advice could include, "Without consent, it's not sex: it's a crime" and "No amount of alcohol buys you the right to another person's body." Statements such as these would suggest that, if sexual assault transpires, fault for the crime lies with its perpetrator (not its target).

\section{We Can Do Better}

After reviewing the long and troubled history of the victim precipitation hypothesis, we struggle to find its appeal. This model simply has too many flaws and inflicts too much harm. Certainly I-O psychology offers better, more practical, and more progressive explanations for workplace mistreatment. Perhaps the features of some employees do make it more likely that hostile 
colleagues will select them for abuse. For instance, many sexual harassers prey on personnel (regardless of gender) who seem weak in some respecte.g., young, poor, petite, undocumented in immigration status (e.g, Cortina \& Berdahl, 2008; Escamilla v. SMS Holdings Corp., 2011; Oncale v. Sundowner Offshore Services, 1998). Some victims are in too precarious a situationoccupationally, financially, legally-to report wrongdoing. The victim precipitation model invites scrutiny of these victim "weaknesses" as triggers for the abuses that befall them. If we aim to understand hostile work behavior, let us instead study those who enact it and the contexts that facilitate it.

I-O psychology is replete with theoretical and practical models that explain workplace mistreatment by focusing on instigators and the social environments that set the stage for their offenses. Three examples include Jennifer Berdahl's (2007a) account of sexual harassment as social status protection, Lilia Cortina's (2008) model of factors that fuel selective incivility, and CREW - a civility intervention in the social context of work (e.g., Laschinger, Leiter, Day, Gilin-Oore, \& Mackinnon, 2012; Osatuke, Moore, Ward, Dyrenforth \& Belton, 2009). What unifies these frameworks is an emphasis on social/structural (rather than victim) causes of workplace abuse. We review each in turn.

\section{Sexual Harassment as Social Status Protection}

Popular culture is rife with images of sexual harassment as something that is welcomed or invited by victims, echoing the victim precipitation model. These popular beliefs have no scientific basis, however. Quite the contrary, studies show how this conduct "derogates, demeans, or humiliates an individual based on that individual's sex" (Berdahl, 2007a, p. 644). Catharine MacKinnon, noted legal scholar, explains that male-on-female sexual harassment is hardly an expression of flirtation or attraction; instead it is a mechanism that "reinforces and expresses women's traditional and inferior role in the labor force" (MacKinnon, 1979, p. 4). It and other forms of sexual violence are fundamentally about social power and dominance (e.g., Brownmiller, 1975; MacKinnon, 1979). Building on this logic, Berdahl (2007a) proposed that "the primary motive underlying all harassment is a desire to protect one's social status when it seems threatened" (p. 641). American society is marked by a gendered (and racialized) hierarchy that results in inequitable access to resources and opportunities; in general, white men hold the greatest access to social power, status, and capital. Harassment serves as a corrective punishment against people who challenge this hierarchy-instigated, for example, against women who are "too assertive, too dominant, or simply too present in traditionally masculine domains of work" (Konik \& Cortina, 2008, p. 319; see also Berdahl, 2007b; Leskinen, Rabelo \& Cortina, 2015). In this way, the larger sociocultural context that is stratified by gender permeates 
organizational life, and harassment is one means of preserving or reinforcing that stratification (Berdahl, 2007a).

Perpetrator research supports these theories of sexual harassment as a tool of social power. John Pryor (1987), for example, found that men who endorse beliefs about social and sexual male dominance are more likely to (1) imagine themselves sexually harassing women in hypothetical scenarios, and (2) engage in actual sexual harassment against women (confederates) during in-person interactions. As Berdahl's (2007a) theory would suggest, the motivation to perpetrate harassment is best predicted not by the victim's personality or behavior but rather by the perpetrator's attitudes about dominance and hierarchy. Research further finds that sexual harassment perpetrators are more likely to be higher (vs. lower) in status (e.g., Lopez, Hodson, \& Roscigno, 2009; O'Connell \& Korabik, 2000; Sojo, Wood, \& Genat, 2016). In this work, perpetrator characteristics-including social location-are key to the incidence of harassment.

\section{Selective Incivility as Modern Discrimination in Organizations}

Research on a more subtle but pervasive form of workplace hostilityincivility-lends further support to the notion that mistreatment often functions to preserve power differentials. According to Cortina (2008),

... incivility, in some cases, is not "general" at all, instead representing contemporary manifes-
tations of gender and racial bias in the workplace. That is, with the rise of taboos, policies, and
laws prohibiting discrimination against specific social groups, blatant intentions and efforts to
alienate women and minorities from organizational life are no longer tolerated. However, one
can mask discrimination (even without realizing it) behind everyday acts of incivility. (p. 55)

This incivility is "selective" (i.e., discriminatory), with employees from marginalized groups being disproportionately targeted (e.g., racial/ethnic minorities, sexual minorities, older adults; Cortina, 2008; Kabat-Farr \& Cortina, 2012). Power plays a prominent role in these dynamics, granting those at the top of the social structure excessive ability to act on their biases (via uncivil conduct) and protect entrenched hierarchies.

Supporting selective incivility theory, research suggests that women, people of color, and members of both of these groups (i.e., black women) encounter the highest frequencies of workplace incivility (Cortina, KabatFarr, Leskinen, Huerta, \& Magley, 2013). Likewise, in a study of law professors, sexual minority women reported significantly higher levels of incivility relative to heterosexual women and men of any sexual orientation (Zurbrügg \& Miner, 2016). Women attendees of professional conferences also describe more uncivil treatment than their male counterparts (Settles \& O'Connor, 2014). Cortina (2008) explains how these discriminatory patterns of disrespect can arise not only from conscious bias and selective targeting on the part of instigators, but also from asymmetrical social roles, attitudes, and 
power. Similar findings are emerging in studies of workplace microaggression, a concept not unlike selective incivility (e.g., Basford, Offermann \& Behrend, 2014; King et al., 2011; Offermann et al., 2014).

\section{CREW: Intervening in the Social Context of Work}

Interventions to reduce the incidence and impact of workplace mistreatment can target various levels of analysis, including individuals, workgroups, and organizations. If we understand and approach this problem from a victim precipitation perspective, interventions would focus on individual employees-we would advise potential or actual victims of abuse to modify their physical appearance, attitudes, actions, or personalities to avoid "inciting" others to behave badly. Offering more promising solutions are programs such as CREW (Civility, Respect, and Engagement in the Workplace), which intervenes in organizational culture (Osatuke et al., 2009). The program is structured and rigorous yet also adaptive to the unique needs of a given workgroup. A standard CREW intervention begins with employees brainstorming ways of fostering civility, resulting in a list of workgroup strengths and areas for improvement. They then collectively generate a plan of action that is continually implemented, evaluated, and modified as needed. Weekly meetings proceed over months to reiterate the process: problem diagnosis, identification of course of action, implementation, and evaluation (Osatuke et al., 2009).

Field studies suggest that the CREW program successfully reduces workplace incivility while boosting respect (Laschinger et al., 2012; Leiter, Laschinger, Day, \& Oore, 2011; Osatuke et al., 2009). CREW has yielded additional benefits for employees and organizations, including lower burnout and absenteeism, and greater perceptions of empowerment, support, resources, and trust in management (Laschinger et al., 2012; Leiter et al., 2011). CREW achieves these objectives by intervening in the social context of work - that is, it strives for change in workplace culture and group norms.

In summary, what the Berdahl, Cortina, and CREW frameworks share in common is attention to social-structural forces that motivate employees to treat others with (dis)respect. They identify targets for intervention in the social environment of the workplace, reflecting the belief that social change can foster individual change; the ultimate goal is to prevent workplace abuse altogether. What these models do not do is place the burden of change on would-be victims.

\section{From Victim Precipitation to Perpetrator Predation Shifting the Paradigm}

Still, the skeptical reader might wonder what to make of colleagues who are more likely to suffer abuse than others. Perhaps they are targeted 
for reasons that make them unpleasant to work with, such as being lazy, irritable, or simply unlikeable. Cortina (2017) has proposed perpetrator predation as a useful framework for understanding these dynamics. According to Merriam-Webster, a "predator" is a person who "lives by predation," or "looks for other people in order to use, control, or harm them in some way." With a perpetrator predation lens, one can still "fall prey" to victimization more often than others, which might be partly attributable to one's own characteristics (e.g., social skill deficits, personality quirks, intellectual disabilities); this framework, however, draws our attention to the individual who targets those characteristics. It also brings power into the picture, with power disparities often separating predator from prey. As Bennett Tepper and colleagues (2011) explain, "potential aggressors choose targets strategically, focusing their hostility on people who seem difficult to like and/or those who appear to be vulnerable and unable to defend themselves" ( $\mathrm{p}$. 283). They used this reasoning to illustrate victim precipitation, but really this dynamic is better described as perpetrator predation.

The perpetrator predation framework puts agency and control clearly into the hands of perpetrators. Again citing Merriam-Webster, an "agent" is "a person or thing that causes something to happen" and "one that acts or exerts power." In cases of workplace aggression, aggressors are the agents. They are typically adults who should understand right from wrong. Most jobs require that they be sober, alert, and awake-that is, fully in command of their faculties and in control of their behaviors. No amount of unpleasantness, underperformance, or unprofessionalism on the part of the victim should absolve perpetrators of responsibility for their own conduct. A victim's traits or behaviors might help us understand why the instigator chose that particular person for abuse, but we must always emphasize that it was the instigator, not the victim, who did the choosing and abusing. That reality stays front and center when viewed through a perpetrator predation lens (Cortina, 2017).

With verbs such as "target," "select," and "prey on," Cortina's (2017) intention is not to imply that all perpetrators have insight into the selective nature of their conduct, or act out of conscious malice. We know from years of research in social psychology that prejudice can prompt action, whether the actor realizes it or not. That is, stereotypes shape people's behavior even without their intention, awareness, or control (e.g., Devine, 1989; Greenwald \& Banaji, 1995). An individual may therefore harbor implicit biases against certain groups and then mistreat members of those groups (e.g., women, immigrants, Muslims); that person may have no awareness of the bigotry underlying this behavior. Alternatively, one could be fully aware of one's own prejudices and selectively abuse particular colleagues with full understanding and intent. The concept of perpetrator predation captures both possibilities. 
Cortina (2017) elaborates on the utility of the perpetrator predation concept, explaining that, "Perpetrator predation is not a 'model' in the sense of specifying a particular set of variables as cause, consequence, or boundary condition for aggression. It is more of a paradigm - that is, a broad framework or analytic lens ... a guiding frame through which empirical observations can be viewed and interpreted" (p. 128). This paradigm can be applied to each stage of the scientific process, from hypothesis development to research design to data analysis and interpretation. A perpetrator predation lens can also inform practice-guiding efforts to identify, interrupt, investigate, and remediate workplace mistreatment.

Perpetrator predation could explain many (if not most) workplace mistreatment findings viewed as evidence of victim precipitation. For example, studies have claimed that employee-victims invite abuse through their own uncivil conduct (Scott et al., 2013), neurotic personality traits (Milam et al., 2009), and poor job performance (Tepper et al., 2011). Recasting these results, we could instead conclude that employee-offenders selectively target personnel perceived as uncivil, neurotic, or incompetent. The key findings remain unchanged, but the perpetrator predation analytic alters their framing and interpretation. This would also alter implications for intervention, suggesting need for change within the abuser and/or the social context within which he or she operates. In short, perpetrator predation is a paradigm for science and practice, offering more practical and progressive ways of thinking about workplace mistreatment.

\section{Illustrating Perpetrator Predation}

To illustrate the perpetrator predation framework, we turn to examples from two lines of research: addressing the victimization of employees based on their conflict management style (Aquino, 2000) and job performance (Kim \& Glomb, 2014).

Aquino (2000) invokes the victim precipitation model when hypothesizing that certain conflict management styles invite aggression. He focuses in particular on so-called "submissive" and "provocative" victims, a dichotomy derived from research on bullying among Swedish schoolboys (Olweus, 1978). According to Aquino, "both victim types may participate to some degree in their own victimization" (2000, p. 173). A central proposition is that when one's style of conflict management is either passive (namely, avoidant or obliging) or aggressive (i.e., dominating in a way that emphasizes one's own interests), the individual will elicit higher rates of victimization; Aquino adds that this especially should be true for lower-status employees. He also hypothesizes that employees who adopt integrating styles of conflict management (i.e., showing empathy and concern for both one's own 
interests and those of the opposing party) should encounter less victimization, especially if they are higher status.

Based on a self-report survey of public utility employees, Aquino (2000) finds that both obliging and integrating styles predict perceived victimization among low-status workers. He then concludes that, "By attempting to be integrative, which is an assertive conflict behavior, low status employees appear to increase the frequency with which they are victimized by others. Yet being overly obliging also appears to increase their chances of being victimized" (Aquino, 2000, p. 189). Using victim precipitation reasoning, this interpretation locates the cause of the misbehavior within its targets; it implicitly blames employee-victims for their colleagues' wrongdoing. In a later section on implications for violence reduction, Aquino maintains this focus on victims, offering advice for how they can go about preventing abuse and "eliciting more positive treatment" from others (2000, p. 189).

If we approached these same findings from a perpetrator predation perspective, we would ask different questions and arrive at different conclusions. For example, both integrating and obliging styles are marked by empathy and high concern for others' interests, so we could ask what characteristics or attitudes lead employees to mistreat colleagues who show concern for others. We could also ask what features of the work context (e.g., local social norms, competitive climates) encourage personnel to abuse empathetic coworkers. This framing would make it clear who is enacting the aggression, and under what circumstances. It would stand in contrast to Aquino's (2000) article, which in many places erases the perpetrator entirely from the narrative (e.g., p. 173: "Some become targets of aggression because they behave passively"; p. 189: "Victims sometimes precipitate aggressive action into the organizational milieu").

In a second example citing the victim precipitation model, Eugene Kim and Theresa Glomb (2014) suggest that "high-performing employees may instigate unfavorable upward social comparison from fellow group members (i.e., potential perpetrators), which results in harmful behaviors against high performers" (p. 620). Group member envy is hypothesized as a key mediating mechanism in these events. This victim precipitation framing implicitly holds victims accountable for their coworkers' thoughts and emotions. The concept of perpetrator predation could capture the same dynamics, yielding propositions that workgroups respond to high performers with envy and upward social comparison, and this prompts aggression against those high performers (Cortina, 2017). This is essentially the argument developed by Kim and Glomb (2014): "Following unfavorable social comparison with high performers, other work group members may experience negative psychological states (e.g., lowered self-evaluations, emotions of envy), which results in 
harmful behaviors against high performers" (pp. 620-621). This explanation is straightforward and parsimonious; to make sense of the results, there is no need for the victim precipitation model and its tenuous assumptions about unconscious invitations on the part of the victim.

The issues we raise are not simply a matter of semantics or rhetoric; rather, the perpetrator predation paradigm can alter implications for practice in organizations (Cortina, 2017). Continuing with the same example, Kim and Glomb (2014) propose that high performers may reduce victimization by "avoiding the spotlight, downplaying accomplishments or behaving in a humble manner in their interactions with their coworkers" (p. 629). This advice tacitly places responsibility on victims for managing misconduct in others, in line with victim precipitation thinking. The recommended actions can also be professionally damaging: masking one's own accomplishments and successes can reduce chances for recognitions, bonuses, awards, promotions, and other career-advancing opportunities. A perpetrator predation framing would suggest different practical interventions, such as training personnel (would-be wrongdoers) on emotion regulation. For example, organizational development workshops could teach employees how to prevent the activation of negative emotion (e.g., envy) or prevent the translation of negative emotion into negative action (aggression). Teams could also participate in CREW-style trainings to enhance their climates of respect and appreciation, which could head off dysfunctional team processes. With this paradigm shift, the burden of change falls to people with the proclivity to harm, their leaders, and their social/structural contexts.

\section{Closing Thoughts}

In writing this article, we reviewed the checkered history of the victim precipitation hypothesis as applied to violence and victimization. According to many scientists and practitioners, this body of scholarship suffers from empirical, logical, and practical flaws-some quite serious (e.g., victim precipitation ideology facilitating the exoneration of violent criminals). Yet, this model is taking hold in I-O psychology.

Perhaps our I-O colleagues have not had opportunity to read the original writings on victim precipitation (e.g., by Amir, 1967; von Hentig, 1940; Wolfgang, 1957). If they had, they might share our concerns-seeing this work as obsolete and, in places, offensive. Moreover, the many criticisms of victim precipitation might give them pause, and the distortions this model brings to the criminal justice process might give them alarm. Hopefully others in I-O would reach the same conclusion we did: victim precipitation is an archaic, regressive ideology. Criminologists have long since abandoned it, and so should we. 
I-O psychology has stronger, more practical, and arguably more progressive frameworks for investigating and remediating victimization in organizations. We reviewed three specific examples, and there are many more. We also discussed a broad analytic paradigm-perpetrator predation-as a way to think about workplace abuse without blaming the abused. Our larger point is that I-O has plenty of interesting ideas (and new ones emerging every day) for making sense of hostile work behavior. There is no need to fall back on outdated, discredited models. Let us move past that old scholarship and call for new science and new solutions to problems of workplace mistreatment.

\section{References}

Amir, M. (1967). Victim precipitated forcible rape. Journal of Criminal Law, Criminology and Police Science, 58, 493-502.

Aquino, K. (2000). Structural and individual determinants of workplace victimization: The effects of hierarchical status and conflict management style. Journal of Management, 26(2), 171-193. doi:10.1177/014920630002600201

Aquino, K., \& Bradfield, M. (2000). Perceived victimization in the workplace: The role of situational factors and victim characteristics. Organization Science, 11(5), 525-537. doi:10.1287/orsc.11.5.525.15205

Aquino, K., \& Byron, K. (2002). Dominating interpersonal behavior and perceived victimization in groups: Evidence for a curvilinear relationship. Journal of Management, 28(1), 69-87. doi:10.1177/014920630202800105

Aquino, K., Grover, S. L., Bradfield, M., \& Allen, D. G. (1999). The effects of negative affectivity, hierarchical status, and self-determination on workplace victimization. Academy of Management Journal, 42(3), 260-272.

Aquino, K., \& Lamertz, K. (2004). A relational model of workplace victimization: Social roles and patterns of victimization in dyadic relationships. Journal of Applied Psychology, 89(6), 1023-1034. doi:10.1037/0021-9010.89.6.1023

Basford, T. E, Offermann, L. R. \& Behrend, T. S. (2014). Do you see what I see? Perceptions of gender microaggressions in the workplace. Psychology of Women Quarterly, 38(3), 340-349.

Bateson, R. (2012). Crime victimization and political participation. American Political Science Review, 106(3), 570-587.

Berdahl, J. L. (2007a). Harassment based on sex: Protecting social status in the context of gender hierarchy. Academy of Management Review, 32(2), 641-658. doi:10.5465/AMR.2007.24351879

Berdahl, J. L. (2007b). The sexual harassment of uppity women. Journal of Applied Psychology, 92(2), $425-437$.

Berger, R. J., \& Searles, P. (1985). Victim-offender interaction in rape: Victimological, situational, and feminist perspectives. Women's Studies Quarterly, 13(3/4), 9-15.

Brekke, N., \& Borgida, E. (1988). Expert psychological testimony in rape trials: A social-cognitive analysis. Journal of Personality and Social Psychology, 55(3), 372-386. doi:10.1037/00223514.55.3.372

Brownmiller, S. (1975). Against our will: Women and rape. New York: Simon \& Schuster.

Burt, M. R. (1980). Cultural myths and supports for rape. Journal of Personality and Social Psychology, 38(2), 217-230. doi:10.1037/0022-3514.38.2.217

Campbell, R., Fehler Cabral, G., Pierce, S. J., Sharma, D. B., Bybee, D., Shaw, J., ... Feeney, H. (2015). The Detroit Sexual Assault Kit (SAK) Action Research Project (ARP), Final report. Retrieved from https://www.ncjrs.gov/pdffiles1/nij/grants/248680.pdf 
Chan, M. E., \& McAllister, D. J. (2014). Abusive supervision through the lens of employee state paranoia. Academy of Management Review, 39(1), 44-66. doi:10.5465/amr.2011.0419

Coates, L., \& Wade, A. (2004). Telling it like it isn't: Obscuring perpetrator responsibility for violent crime. Discourse \& Society, 15(5), 499-526. doi:10.1177/0957926504045031

Cohn, E. G., \& Farrington, D. P. (1994). Who are the most influential criminologists in the Englishspeaking world. British Journal of Criminology, 34(2), 204-225.

Cortina, L. M. (2008). Unseen injustice: Incivility as modern discrimination in organizations. Academy of Management Review, 33(1), 55-75. doi:10.5465/amr.2008.27745097

Cortina, L. M. (2017). From victim precipitation to perpetrator predation: Toward a new paradigm for understanding workplace aggression. In N. Bowling \& M. S. Hershcovis (Eds.), Research and theory on workplace aggression (pp. 121-135). New York: Cambridge University Press.

Cortina, L. M., \& Berdahl, J. L. (2008). Sexual harassment in organizations: A decade of research in review. In C. C. J. Barling (Ed.), Handbook of organizational behavior: Micro perspectives (pp. 469-497). Thousand Oaks, CA: Sage.

Cortina, L. M., Kabat-Farr, D., Leskinen, E. A., Huerta, M., \& Magley, V. J. (2013). Selective incivility as modern discrimination in organizations: Evidence and impact. Journal of Management, 39(6), 1579-1605. doi:10.1177/0149206311418835

Cowan, G. (2000). Beliefs about the causes of four types of rape. Sex Roles, 42(9), 807-823. doi:10.1023/a:1007042215614

Devine, P. G. (1989). Stereotypes and prejudice: The automatic and controlled components. Journal of Personality and Social Psychology, 56, 5-18.

Eigenberg, H., \& Garland, T. (2003). Victim blaming. In L. J. Moriarty (Ed.), Controversies in victimology (pp. 15-24). Newark, NJ: Routledge.

Elias, R. (1986). The politics of victimization: Victims, victimology, and human rights. New York: Oxford University Press.

Escamilla v. SMS Holdings Corp., 2011, WL 5025254 (D. Minn. Oct. 21, 2011).

Franklin, C. W., \& Franklin, A. P. (1976). Victimology revisited: A critique and suggestions for future direction. Criminology, 14(1), 125-136. doi:10.1111/j.1745-9125.1976.tb00008.x

Greenwald, A. G., \& Banaji, M. R. (1995). Implicit social cognition: Attitudes, self-esteeem, and stereotypes. Psychological Review, 102, 4-27.

Henle, C. A., \& Gross, M. A. (2014). What have I done to deserve this? Effects of employee personality and emotion on abusive supervision. Journal of Business Ethics, 122(3), 461-474.

Human Rights Watch. (2010). "I used to think the law would protect me": Illinois's failure to test rape kits. New York: Author.

International Association of Chiefs of Police (IACP). (2005). Sexual assault incident reports: Investigative strategies. Alexandria, VA: Author.

Kabat-Farr, D., \& Cortina, L. M. (2012). Selective incivility: Gender, race, and the discriminatory workplace. In S. Fox \& T. Lituchy (Eds.), Gender and the dysfunctional workplace (pp. 107-119). Northhampton, MA: Edward Elgar Publishing.

Kim, E., \& Glomb, T. M. (2014). Victimization of high performers: The roles of envy and work group identification. Journal of Applied Psychology, 99(4), 619-634. doi:10.1037/a0035789

King, E. B., Dunleavy, D. G., Dunleavy, E. M., Jaffer, S., Morgan, W. B., Elder, K., \& Graebner, R. (2011). Discrimination in the 21st century: Are science and the law aligned? Psychology, Public Policy, and Law, 17(1), 54-75.

Konik, J., \& Cortina, L. M. (2008). Policing gender at work: Intersections of harassment based on sex and sexuality. Social Justice Research, 21(3), 313-337.

Kutash, I. L. (1978). Treating the victim of aggression. In I. L. Kutash, S. B. Kutash, \& L. B. Schlesinger (Eds.), Violence: Perspectives on murder and aggression (pp. 446-461). San Francisco, CA: JosseyBass.

Kutash, I. L. (1984). Aggression victimology: Treatment of the victim. In H. S. Strean, (Ed.), Psychoanalytic approaches with the hostile and violent patient (pp. 47-64). New York: Routledge. 
Laschinger, H. K. S., Leiter, M. P., Day, A., Gilin-Oore, D., \& Mackinnon, S. P. (2012). Building empowering work environments that foster civility and organizational trust: Testing an intervention. Nursing Research, 61(5), 316-325.

LeGrand, C. E. (1973). Rape and rape laws: Sexism in society and law. California Law Review, 61, 919-941. doi:10.15779/Z384B4V

Leiter, M. P., Laschinger, H. K. S., Day, A., \& Oore, D. G. (2011). The impact of civility interventions on employee social behavior, distress, and attitudes. Journal of Applied Psychology, 96(6), 12581274. doi:10.1037/a0024442

Leskinen, E. A., Rabelo, V. C., \& Cortina, L. M. (2015). Gender stereotyping and harassment: A "catch22" for women in the workplace. Psychology, Public Policy, and Law, 21(2), 192-204.

Lonsway, K. A., Cortina, L. M., \& Magley, V. J. (2008). Sexual harassment mythology: Definition, conceptualization, and measurement. Sex Roles, 58(9), 599-615. doi:10.1007/s11199-007-9367-1

Lonsway, K. A., \& Fitzgerald, L. F. (1994). Rape myths: In review. Psychology of Women Quarterly, 18(2), 133-164. doi:10.1111/j.1471-6402.1994.tb00448.x

Lonsway, K. A., \& Fitzgerald, L. F. (1995). Attitudinal antecedents of rape myth acceptance: A theoretical and empirical reexamination. Journal of Personality and Social Psychology, 68(4), 704-711.

Lopez, S. H., Hodson, R., \& Roscigno, V. J. (2009). Power, status, and abuse at work: General and sexual harassment compared. Sociological Quarterly, 50(1), 3-27. doi:10.1111/j.15338525.2008.01131.x

MacKinnon, C. A. (1979). Sexual harassment of working women: A case of sex discrimination. New Haven, CT: Yale University Press.

Meloy, M. L., \& Miller, S. L. (2010). The victimization of women: Law, policies, and politics. New York: Oxford University Press.

Mendelsohn, B. (1956). The victimology. Etudes Internationale de Psycho-Sociologie Criminell, (JulySeptember), 23-26.

Mendelsohn, B. (1958). La victimologie. Revue Française de Psychanalyse, 22(1), 95-120.

Milam, A. C., Spitzmueller, C., \& Penney, L. M. (2009). Investigating individual differences among targets of workplace incivility. Journal of Occupational Health Psychology, 14(1), 58-69. doi:10.1037/a0012683

O'Connell, C. E., \& Korabik, K. (2000). Sexual harassment: The relationship of personal vulnerability, work context, perpetrator status, and type of harassment to outcomes. Journal of Vocational Behavior, 56(3), 299-329. doi:10.1006/jvbe.1999.1717

Offermann, L. R., Basford, T. E., Graebner, R., Jaffer, S., De Graaf, S. B., \& Kaminsky, S. E. (2014). See no evil: Color blindness and perceptions of subtle racial discrimination in the workplace. Cultural Diversity and Ethnic Minority Psychology, 20(4), 499-507. doi:10.1037/a0037237

Oncale v. Sundowner Offshore Services, 523 U.S. 75 (1998)

Olweus, D. (1978). Aggression in the schools: Bullies and whipping boys. New York: Wiley.

Osatuke, K., Moore, S. C., Ward, C., Dyrenforth, S. R., \& Belton, L. (2009). Civility, Respect, Engagement in the Workforce (CREW): Nationwide organization development intervention at Veterans Health Administration. The Journal of Applied Behavioral Science, 45(3), 384-410. doi:10.1177/0021886309335067

Payne, D. L., Lonsway, K. A., \& Fitzgerald, L. F. (1999). Rape myth acceptance: Exploration of its structure and its measurement using the Illinois Rape Myth Acceptance Scale. Journal of Research in Personality, 33(1), 27-68. doi:10.1006/jrpe.1998.2238

Pryor, J. B. (1987). Sexual harassment proclivities in men. Sex Roles, 17(5), 269-290. doi:10.1007/bf00288453

Ressler, R. K., Burgess, A. W., Douglas, J. E., Hartman, C. R., \& D’Agostino, R. B. (1986). Sexual killers and their victims identifying patterns through crime scene analysis. Journal of Interpersonal Violence, 1(3), 288-308. doi:10.1177/088626086001003003

Samnani, A. K. (2013). "Is this bullying?" Understanding target and witness reactions. Journal of Managerial Psychology, 28(3), 290-305. doi:10.1108/02683941311321196 
Samnani, A. K., \& Singh, P. (2016). Workplace bullying: Considering the interaction between individual and work environment. Journal of Business Ethics, 139(3), 537-549.

Scott, K. L., Restubog, S. L. D., \& Zagenczyk, T. J. (2013). A social exchange-based model of the antecedents of workplace exclusion. Journal of Applied Psychology, 98(1), 37-48. doi:10.1037/a0030135

Schwendinger, J. R., \& Schwendinger, H. (1974). Rape myths: In legal, theoretical, and everyday practice. Crime and Social Justice, 1, 18-26.

Settles, I. H., \& O'Connor, R. C. (2014). Incivility at academic conferences: Gender differences and the mediating role of climate. Sex Roles, 71(1-2), 71-82.

Sojo, V.E., Wood, R. E., \& Genat, A.E. (2016). Harmful workplace experiences and women's occupational well-being: A meta-analysis. Psychology of Women Quarterly, 40(1), 10-40. doi:10.1177/0361684315599346

Tepper, B. J., Duffy, M. K., Henle, C. A., \& Lambert, L. S. (2006). Procedural injustice, victim precipitation, and abusive supervision. Personnel Psychology, 59(1), 101-123. doi:10.1111/j.17446570.2006.00725.x

Tepper, B. J., Moss, S. E., \& Duffy, M. K. (2011). Predictors of abusive supervision: Supervisor perceptions of deep-level dissimilarity, relationship conflict, and subordinate performance. Academy of Management Journal, 54(2), 279-294. doi:10.5465/amj.2011.60263085

Tetreault, P. A. (1989). Rape myth acceptance: A case for providing educational expert testimony in rape jury trials. Behavioral Sciences \& the Law, 7(2), 243-257. doi:10.1002/bsl.2370070208

The Weiner Report. (2002). DNA justice: Cases solved at last. New York: Author.

Timmer, D. A., \& Norman, W. H. (1984). Ideology of victim precipitation. Criminal Justice Review, 9(2), 63-68. doi:10.1177/073401688400900209

von Hentig, H. (1940). Remarks on the interaction of perpetrator and victim. Journal of Criminal Law and Criminology, 31(3), 303-309. doi:10.2307/1137415

von Hentig, H. (1948). The criminal \& his victim: Studies in the sociobiology of crime. New Haven, CT: Yale University Press.

Weis, K., \& Borges, S. S. (1973). Victimology and rape: The case of the legitimate victim. Issues in Criminology, 8(2), 71-115.

Wiederspahn, A. (2013, September 12). Military catches flak for poster that warns of sexual assaults. MSNBC. Retrieved from http://www.msnbc.com/jansing-co/ military-catches-flak-poster-warns

Wolfgang, M. F. (1957). Victim precipitated criminal homicide. Journal of Criminal Law, Criminology, and Police Science, 48(1), 1-11. doi:10.2307/1140160

Wu, L. Z., Birtch, T. A., Chiang, F. F., \& Zhang, H. (In press). Perceptions of negative workplace gossip: A self-consistency theory framework. Journal of Management. doi: 10.1177/0149206316632057.

Wu, L., Wei, L., \& Hui, C. (2011). Dispositional antecedents and consequences of workplace ostracism: An empirical examination. Frontiers of Business Research in China, 5(1), 23-44.

Zurbrügg, L., \& Miner, K. N. (2016). Gender, sexual orientation, and workplace incivility: Who is most targeted and who is most harmed? Frontiers in Psychology, 7, 1-12. doi:10.3389/fpsyg.2016.00565 